\title{
The regional recovery of Nucella lapillus populations from marine pollution, facilitated by man-made structures
}

\author{
SIMON BRAY ${ }^{1}$, EMILY C. MCVEAN ${ }^{1}$, ANDREW NELSON ${ }^{2}$, ROGER J.H. HERBERT ${ }^{3}$, STEPHEN J HAWKINS ${ }^{4}$ \\ AND MALCOLM D. HUDSON ${ }^{1}$ \\ ${ }^{1}$ Faculty of Engineering and Environment, University of Southampton, Highfield, Southampton, Hampshire, SO17 1BJ, \\ ${ }^{2}$ Field Studies Council, Nettlecombe Court, The Leonard Wills Field Centre, Williton, Taunton, Somerset, TA4 4 HT, ${ }^{3}$ School of \\ Conservation Sciences, Christchurch House, Bournemouth University Fern Barrow Talbot, Campus, Poole, Dorset, BH12 5BB, \\ ${ }^{4}$ Faculty of Natural and Environmental Sciences, University of Southampton, Highfield, Southampton, Hampshire SO17 1BJ, UK
}

\begin{abstract}
The dogwhelk Nucella lapillus experienced localized extinction in the 1980s and 1990s due to the use of tributyltin (TBT) antifoulants, causing imposex in females. The aim of this study was to establish the extent of the return of the species across the mainland coast of central southern England as TBT use has been progressively restricted, and to quantify the extent of imposex impact on the populations present. We surveyed from Poole to Selsey where isolated populations had become extinct, and the Isle of Wight where some populations had persisted. We found evidence that since TBT restrictions, recolonization and colonization by $\mathrm{N}$. lapillus has been rapid. By 2007-2008, of the eleven surveyed mainland sites, seven were colonized, although indications of reduced imposex impacts were mixed. Distribution had also extended on the Isle of Wight and populations were larger with less imposex impact in sites with long term populations. The lack of continuous suitable habitat blocks and the hydrodynamic complexity of the region, leads us to hypothesize that recovery has been facilitated by man-made structures which may be acting as 'stepping stones'. Populations that have become established on engineered structures such as sea walls, breakwaters and rock groynes demonstrate accelerated recovery in the region as TBT in the environment has generally declined. Sites with suitable substrates and food sources near to ports were either not recolonized or had small populations with imposex evident. For species with a short pelagic larval stage or with direct development, population connectivity between patches of harder substrata along hydrodynamically complex coastlines may be greater than previously thought.
\end{abstract}

Keywords: imposex, tributyltin, TBT, dogwhelk Nucella lapillus, recolonization, sea defences, marine pollution indicator

Submitted 19 May 2011; accepted 24 May 2011

\section{INTRDDUCTION}

There is growing interest in the reproductive connectivity of marine organism populations associated with the design of Marine Protected Area networks. Accordingly the role of man-made structures in facilitating colonization of hard substrata, and subsequent dispersal of reproductive propagules or juvenile stages, is receiving worthwhile attention (e.g. Bacchiocchi \& Airoldi, 2003; Moschella et al., 2005; Hawkins et al., 2008, 2009). However, it may be that as many rare species have poor, or poorly understood, dispersal traits, due either to a short pelagic larval phase or direct development, the importance of artificial substrata in their persistence and movement may be underestimated.

The dogwhelk Nucella lapillus (L.) is a predatory gastropod inhabiting intertidal and subtidal hard structures along North Atlantic shores. The species is carnivorous, feeding preferentially on sedentary prey (e.g. barnacles, by prizing plates

Corresponding author:

M.D. Hudson

Email: mdh@soton.ac.uk apart; and mussels by boring through the shell) (Moore, 1938; Morgan, 1972; Crothers, 1985), but can adapt to other prey types (Largen, 1967; Crothers, 1985). Having no recognized pelagic stage, upon emergence from capsules fully formed juvenile $N$. lapillus (crawlaways), can migrate down shore where feeding has been observed on the annelid worm Spirorbis borealis (Moore, 1936) or small barnacles (Crothers, 1985). Juvenile N. lapillus have also been observed at the same tidal level as their egg cases sheltering in empty barnacle carapaces (Feare, 1970). It may be considered that direct development may restrict dispersive abilities, but rafting (Bryan et al., 1986; Martel \& Chia, 1991), passive transport (Colson \& Hughes, 2004) or a small amount of air trapped in the shell (Adachi \& Wada, 1999), have been suggested as colonization facilitators in direct developing gastropods. In addition shells of small gastropods (Littorina littorea) have been noted to roll in the surf, in a similar way to saltation in sediments (Amos et al., 2000).

Because of tributyltin (TBT) use as an antifoulant, many UK N. lapillus populations declined or became absent from shores, particularly close to ports (e.g. Spence et al., 1990). Dogwhelks are highly sensitive to TBT (Evans \& Nicholson, 2000) with levels as low as $1 \mathrm{ngl}^{-1}$ inducing imposex 
(imposition of male sex organs on the female) (Matthiessen \& Gibbs, 1998) thus the organism proved to be a sensitive and valuable indicator for marine-TBT levels. In female N. lapillus, imposex advances to irreversible sterility and death occurs as vas deferens growth blocks the anterior oviduct (Gibbs \& Bryan, 1986)

By the 1980s N. lapillus became extinct in areas of high shipping and maritime activity, and, particularly along the UK south coast, many surviving populations were depleted, suffering with high imposex levels (Spence et al., 1990; Bryan \& Gibbs, 1991). In 1985 France was the first nation to place restrictions on TBT use and in 1987 the UK also banned the antifoulant on vessels $<25 \mathrm{~m}$ length overall. Many other nations put in place similar bans (Champ, 2000), however, its use on larger ships continued (Bates \& Benson, 1993). A global ban was finally ratified in September 2008 (Sonak et al., 2009), but there are some difficulties with the legal issues (Gipperth, 2009; Kotrikla, 2009). Following progressive TBT restrictions, UK sites where $N$. lapillus was absent began to be recolonized (Evans et al. 1995; Harding et al., 1997; Bray \& Herbert, 1998; Crothers, 1998, 2003; Birchenough et al., 2002; Colson \& Hughes, 2004). Some populations recovered to pre-TBT densities in just ten years (Colson \& Hughes, 2004) with increasing egg production and changes in population structure documented (Morton, 2009). However, possibly due to residual and potentially continuing contamination (Kotrikla, 2009; Oliveira et al., 2009), the recovery of dogwhelk populations has proved to be slow in some areas (e.g. Smith et al., 2006).

One such area is the Solent region on the UK south coast: a centre for international shipping, and a focus for maritime recreation from Selsey (Sussex) to Poole Harbour (Dorset) and on the Isle of Wight. Much of the coastline is soft sediment, sand, gravel or soft chalk, with hard substrata suitable for $N$. lapillus and their prey few and far between. Isolated dogwhelk populations are believed to have existed historically on the mainland coast at Netley on Southampton Water (Langston et al., 1994) and between Hurst Spit and Calshot (Moore, 1936), but they were not found in surveys in 19861989 (Spence et al., 1990) and 1996-2002 (Bray, 2005). It seems that $N$. lapillus has been absent from much of the mainland coast of central southern England since the 1980s, potentially due to TBT pollution and unsuitable habitat. In the 1970s, large populations were present on the northern Solent coast of the Isle of Wight, mainly on piers and breakwaters. By the mid-1980s, with TBT now extensively used on all kinds of marine vessels, these populations had mostly become extinct, although those on the relatively uncontaminated rocky shores on the island's southern coast remained, albeit significantly affected by imposex (Herbert, 1988; Bray \& Herbert, 1998; Herbert et al., 2000).

Of the $354 \mathrm{~km}$ of developed North Solent coastline approximately $80 \%$ is protected from erosion with a variety of man-made structures (Williams et al., 2009). Over the last two decades sea defences have changed, with combinations of rip-rap, rock armour, concrete breakwaters and rock groynes, which have often replaced wooden structures (Dong, 2004). These have created intermittent artificial 'rocky shores' which may be rapidly colonized by 'fouling organisms' (e.g. Bacchiocchi \& Airoldi, 2003; Chapman \& Bulleri, 2003). Yet, as N. lapillus has no recognized pelagic stage, it could be expected that the colonization or recolonization of these structures, would be slow, even as TBT concentrations potentially diminish (Smith et al., 2006). Moreover, the Solent region has a complex hydrography and tidal regime, that together with fast offshore currents around headlands immediately east and west of the region may create barriers to colonizers from existing populations (Herbert et al., 2007, 2009).

This study was prompted by initial casual observation of dogwhelks on rock groynes constructed at Highcliffe (Christchurch Bay), where N. lapillus were not previously documented. Subsequently the aims were to monitor and record the recovery of $N$. lapillus populations, against TBT decline, on the south coast, and in particular the colonization of man-made substrates across the Selsey-Poole coastline. As they may prove to be source sites for mainland population recovery, data from recovering populations on the Isle of Wight, on both natural and man-made substrate were also included to give a complete regional assessment.

\section{MATERIALS AND METHODS}

The Selsey-Poole coastline, including the Isle of Wight, was surveyed to identify suitable substrates (natural and man-made structures constructed of natural stone or concrete, in moderately exposed or exposed locations) that could be expected to support $N$. lapillus. The distribution of rocky structures was recorded by use of Ordnance Survey maps, data and aerial photographs.

Seven sites between Sandbanks and Calshot were surveyed in 2006. These were re-examined in 2008 in addition to the coast from east of Southampton Water to Selsey, giving a total of eleven mainland sites assessed in detail in 2008. Five sites on the Isle of Wight were surveyed in 2007. These results are compared with historic (1995 onwards) data where available (Bray, 2005).

Where N. lapillus were identified on mainland sites, individuals were counted over three 10-minute timed site searches conducted at low spring tides; Isle of Wight sites were searched in a single 30 minute period, so overall effort was the same. In the mainland surveys shell size was measured to the nearest $0.1 \mathrm{~mm}$. Thirty-five adults were then randomly selected to undergo imposex assessment using methods as defined by Gibbs \& Bryan (1986) and Gibbs et al. (1987) in which the vas deferens sequence (VDS) and relative penis size index (RPSI) are calculated as measures of TBT impact. The VDS in females is assessed through stages o (no VDS) to 6 (oviduct blocked with aborted egg capsules; stage 5 and over are sterile) and the RPSI calculated as the 'bulk' (length ${ }^{3}$ ) of the average female penis length as a percentage of the average male penis length. Imposex was not assessed where low numbers were recorded (where less than 50 individuals were found, although recovering populations on the Isle of Wight were treated conservatively). VDS data have often been presented as the female population mean value (e.g. Evans et al., 1998, 2000). However, as the VDS is assessed through categorical values, they are presented here as the range and median to give a representation of a population's central tendency VDS.

In terms of substrate and food resource, sites were included which appeared suitable for $N$. lapillus, but had none present: for example Hayling and Southsea were unoccupied, but had extensive suitable substrate; Sowley was occupied in 2006, but not in 2008. Food resources were not surveyed in detail in 
heavily industrialized estuaries such as Southampton Water and Portsmouth Harbour where no N. lapillus appeared to be present, apart from Netley (Southampton Water) which was monitored as part of another study (Bray, 2005) (Figure 1; Table 1). Using stratified random $0.25 \mathrm{~m}^{2}$ quadrats, percentage cover of the main $N$. lapillus prey resources, common mussels (Mytilus edulis) and barnacles (Semibalanoides balanoides and Elminius modestus), was assessed in the mid to lower eulittoral zone (Lewis, 1964; Stephenson \& Stephenson, 1949, 1972) as were algae, at each occupied site surveyed in 2008 .

\section{RESULTS}

On the mainland coast between Sandbanks and Selsey Bill, 95 individual or grouped structures, and sub-optimal natural substrates enhanced by anthropogenic debris such as concrete blocks were recorded as having potential to support N. lapillus. Most are within $5 \mathrm{~km}$ of each other, but there is an approximately $13 \mathrm{~km}$ gap between Sandbanks and Hengistbury Head and only a single outfall pipe between Hurst Spit and Langley (2.5 km south-west of Calshot) (Figure 1). Nucella lapillus populations were recorded at eight mainland sites across the study area (in 2006 a single dogwhelk only was recorded at a ninth site, Sowley); seven of the eight populations were on man-made substrates. No dogwhelks were recorded in Southampton Water or Portsmouth Harbour despite suitable habitat in docksides, breakwaters and sea walls, and none were found at Hayling or Southsea despite extensive suitable substrates and relatively 'clean' conditions.

In 2008 the largest population recorded was on rock groynes at Barton-on-Sea (total 307 specimens). Total N. lapillus counts in 2008 were generally slightly lower than those of 2006. (Figure 1; Table 1), however total counts from Highcliffe and Calshot increased in 2008.

Where N. lapillus were recorded, prey assemblages varied from site to site. Hayling Island had the highest percentage barnacle cover $(49.7 \pm 13.4 \%)$, but no $N$. lapillus. The sites with the lowest mean barnacle cover were Sandbanks with $1.0 \%$ ( $\pm 0.6 \mathrm{SE})$; and Selsey (3.0 $\pm 0.4 \%$ barnacle cover) where $N$. lapillus were noted feeding upon the common periwinkle, Littorina littorea (see Crothers, 1985); the only other observed potential prey type present at Sandbanks was limpets on which $N$. lapillus will also forage (Crothers, 1985). An independent sample $t$-test comparison for percentage barnacle cover at Sowley and Selsey showed they were not significantly different, but whilst Selsey supported 276 N. lapillus, none were recorded at Sowley. Although Southsea did not support $N$. lapillus, mean percentage covers of each prey taxon were similar to Hengistbury Head (which supported a dogwhelk population); independent sample $t$-tests showed that the prey assemblages were not significantly different.

In 2006, all mainland sites (Figure 1) showed TBT impacts except Hurst Spit. For 2008, of the seven mainland sites supporting $N$. lapillus sufficient for imposexing, only Highcliffe was unaffected (RPSI, o, VDS, o), a reduction from the 2006 VDS range of $0-4$ (Table 1 ).

In 2006 and 2008 the Sandbanks VDS range was $0-4$. The 2008 Hengistbury Head, Barton-on-Sea and Hurst Spit populations showed little TBT impact. Only one female from each exhibited imposex (Figure 2; Table 1), with the one at Barton-on-Sea at VDS stage 3. Nevertheless, both Barton-on-Sea and Hurst Spit populations had an increased VDS range over 2006 results (Table 1). The remaining mainland locations with populations present (Table 1), Calshot and Selsey, had VDS ranges of $0-3$, but, as with all sites, except Sandbanks in 2006 (Table 1), in both sample years the median VDS value was o, highlighting the dominance of unaffected females. However, in 2008 the similar $\left(>_{40} \%\right)$ percentage of affected females at the sites near commercial ports (Sandbanks and Calshot) highlights the on-going imposex impact at such locations (Table 1). In addition, despite suitable habitat, the other commercial traffic-affected location, Southsea, did not support any individuals, though this may equally be attributable to $N$. lapillus not yet having achieved successful colonization because of TBT impacts.

Mean male penis lengths varied from $1.7 \mathrm{~mm}$ (Calshot) to $3.1 \mathrm{~mm}$ (Barton-on-Sea) in 2008. Sandbanks had the greatest mean female penis length $(0.34 \mathrm{~mm})$ reaching $13.6 \%$ of the mean male penis length $(2.52 \mathrm{~mm})$. This is reflected in the RPSI of $0.25 \%$; all other sites had RPSIs below 0.09\% (Table 1).

Assessment on the Isle of Wight in 2007 showed population recovery on Solent shores (Bembridge, Ventnor and Hanover Point) and man-made structures at Cowes and at Yarmouth. At Bembridge and Hanover Point there were reduced imposex levels compared to 1997 values (Table 2). The other sites were not assessed for imposex in 1997 due to low abundance; Cowes was not assessed in either 1997 or 2007.

Shell lengths varied considerably, ranging from $12.2 \mathrm{~mm}$ (Hurst Spit 2008) to $45.4 \mathrm{~mm}$ (Highcliffe 2006). Hurst Spit (2006) had the highest proportion of small individuals $(7.8 \%$ up to $14 \mathrm{~mm}$ ). Lee-on-Solent's population (2008 only) consisted of only very large individuals ranging from 38.7 to $44.4 \mathrm{~mm}$, although, only five specimens were found at this site. Two sample Kolmogorov-Smirnov Z-tests (KSz) (Siegel, 1956) were applied to the 2006 and 2008 data to determine whether neighbouring populations had similar size-frequencies, that might indicate the presence of metapopulations augmented by dispersers. Barton-on-Sea and Hurst Spit had similar populations in $2006(6.3 \mathrm{~km}$ apart), and Hengistbury Head was similar to both Hurst Spit and Calshot in 2008; (12.1 km and $21.1 \mathrm{~km}$ apart respectively). All other neighbouring sites had significant differences (2006, KSz all others $P<0.01 ; 2008$, all others $P<0.05)$. Analysis of 2006 and 2008 data demonstrated a significant negative logarithmic correlation between abundance and mean shell length $(r=0.73, \mathrm{~N}=14, \mathrm{df}=13, P<0.05 ; y=-3.6678$ $\ln (x)+48.124)$ (Figure 3).

\section{DISCUSSIDN}

The results show an unexpectedly rapid spread of dogwhelks across the Solent into areas which have either never supported known populations, or where they have been extinct for around thirty years. This increase in distribution has taken place as restriction on the use of TBT has tightened, but appears to have been facilitated by the widening occurrence of man-made hard substrates. Where suitable natural habitat was present, such as at Bembridge on the Isle of Wight, engineered structures on the shore may have acted as stepping stones across less favourable habitats thus 


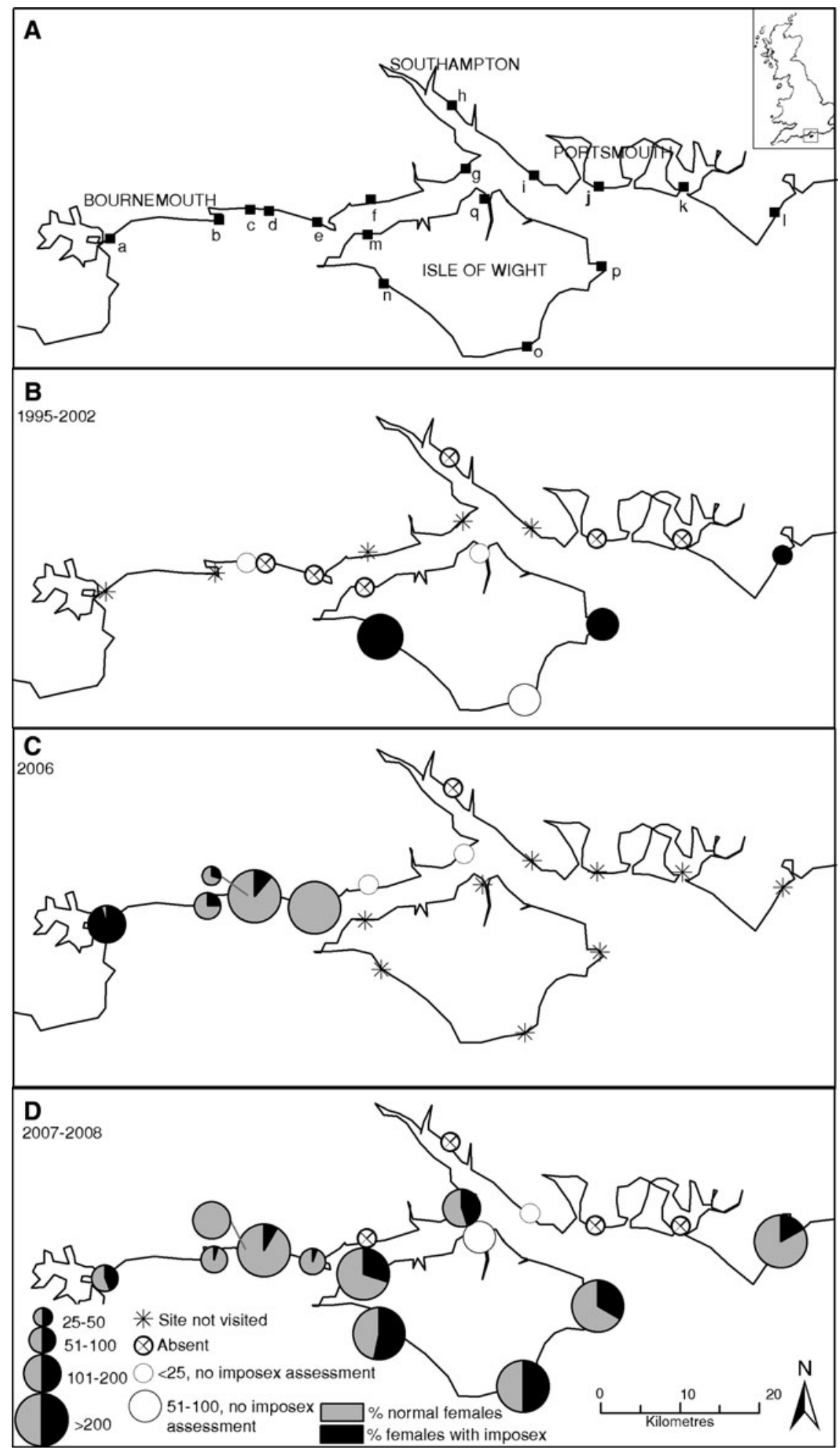

Fig. 1. Population of Nucella lapillus and imposex impact at sites in the Solent, Southern UK. (A) Site locations: a, Sandbanks; b, Hengistbury Head; c, Highcliffe; d, Barton-on-Sea; e, Hurst Spit; f, Sowley; g, Calshot; h, Netley; i, Lee-on-Solent; j, Southsea; k, Hayling Island; l, Selsey Bill; m, Yarmouth; n, Hanover Point; o, Ventnor; p, Bembridge; (B-D) status of populations at each site: (B) 1995-2002; (C) 2006; (D) 2007-2008 (with charts indicating the prevalence of imposex and population size).

accelerating re-colonization and regional recovery of populations. Distances between occupied sites varied from as little as $1.3 \mathrm{~km}$ (Highcliffe to Barton-on-Sea) to $35.6 \mathrm{~km}$ (Lee-on-Solent to Selsey Bill). This investigation confirmed that man-made rocky structures have potential to provide a valuable intertidal habitat for recovering $N$. lapillus populations. However, they are not essential for populations to survive, since N. lapillus were abundant at Selsey Bill, where there was little or no man-made or natural rocky substrate, but areas of gravel, large cobbles and concrete debris stabilized 


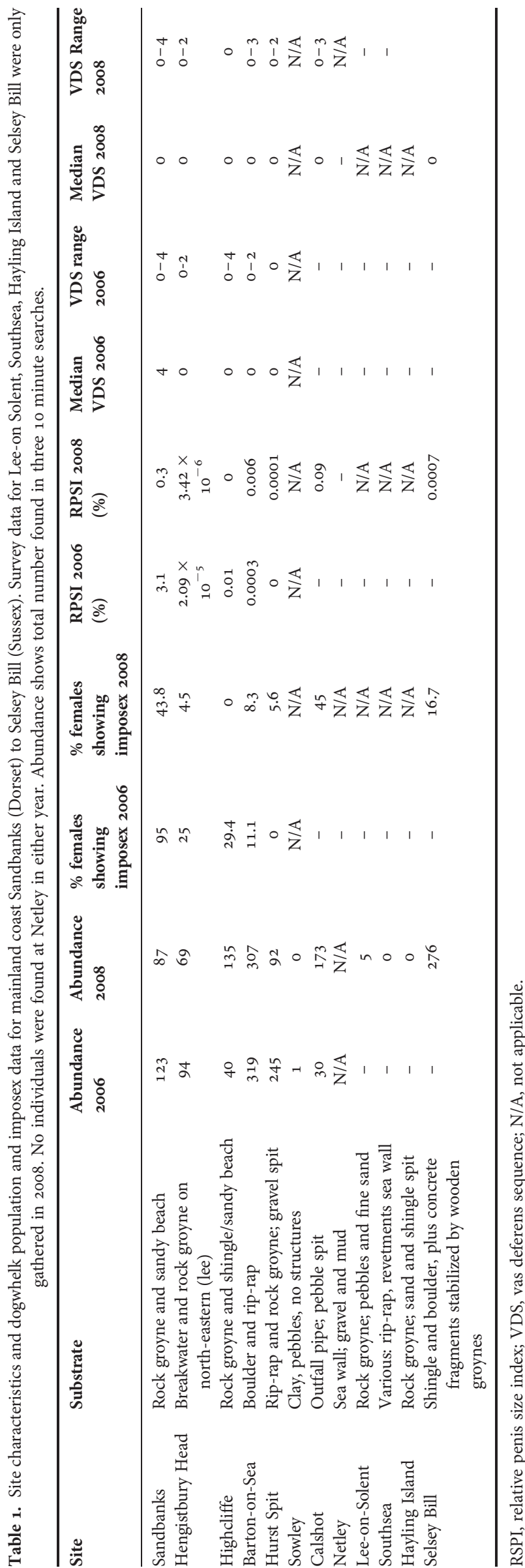

by timber groynes. Nucella lapillus aggregations were present on shingle surrounded single boulders and a highly TBT impacted population was recorded at Selsey as long ago as 1990 (Spence et al., 1990) with evidence of high TBT levels experimentally recorded using imposex indices by Harding et al. (1992).

Whilst six recently established $N$. lapillus populations have been identified, with the mainland Solent dogwhelk distribution apparently having increased significantly, their persistence may be unstable because of the high proportion of juveniles (indicated by the smaller shells). The large population at Barton-on-Sea declined slightly from 2006 to 2008 , while numbers increased at Highcliffe and Selsey; the notable abundance decline at Hurst Spit may be attributed to factors such as wave exposure and predation pressure influencing N. lapillus abundance (Miller et al., 1999) as well as bad weather hindering searches, rather than TBT pollution. 'Abundance' in this study actually refers more to the rate of individuals found (animals per three 10 minute replicate searches), which reflects both the population density and the nature of the area being searched, so is subject to some degree of error; deep crevices take more time to investigate than flat surfaces. However, abundance as recorded appeared to have a significant relationship with shell size; smaller shells were found at sites newly colonized or recovering.

The continued use of TBT antifouling paint on large vessels and the restricted water and sediment movement within ports prevents complete recovery from TBT poisoning (Smith et al., 2006). TBT has been observed to persist in sediments and could potentially provide a 'reservoir' of contamination for decades (Maguire, 2000). Benthic sediments are the primary means of TBT bioaccumulation in deposit feeders, particularly bivalves (Langston et al., 1990). Contaminated sediments could continue to be a TBT pollution source well into this century (Langston \& Pope, 1995). Desorption of TBT from sediments increases concentrations in overlying water to quantities which exceed the Environmental Quality Standard of $2 \mathrm{ng} \mathrm{l}^{-1}$ (Langston \& Pope, 1995). Wave simulation experiments indicate that TBT paint particles move upwards to the sediment surface where it is most available (Eggleton \& Thomas, 2004) and simulated removal of the top sediment layer releases TBT back into the water column, leading to a higher incidence of imposex (Svavarsson et al., 2001). In addition, not only does the disturbance of contaminated sediment cause remobilization of TBT at dredge sites, levels at disposal sites have been implicated in imposex impacts in marine protected areas (Boersma \& Parrish, 1999; Terlizzi et al., 2004).

Ongoing dredging and disposal within the region may threaten complete recovery of $N$. lapillus populations. Measurements of TBT taken from East Brambles Buoy (2.5 km offshore of Calshot, at the entrance to Southampton Water) from February 2000 to February 2007, gave a mean water concentration of $2.465 \mathrm{ng} \mathrm{l}^{-1}$ (unpublished data, D. Lowthion, Environment Agency, 2007), enough to cause imposex in dogwhelks (Gibbs et al., 1987) and Calshot had $45 \%$ of females with imposex in 2008 (Table 1). Thomas et al. $(2000,2001)$ indicated that TBT would be a factor in non-target organism impacts in the region for some time. This may continue to be reflected by the intensity of maritime activity around the Port of Southampton as well as sediment disturbance due to regular large scale dredging.

It is unclear why N. lapillus has not yet colonized Southsea, close to Portsmouth Harbour. Assessment of the potential 


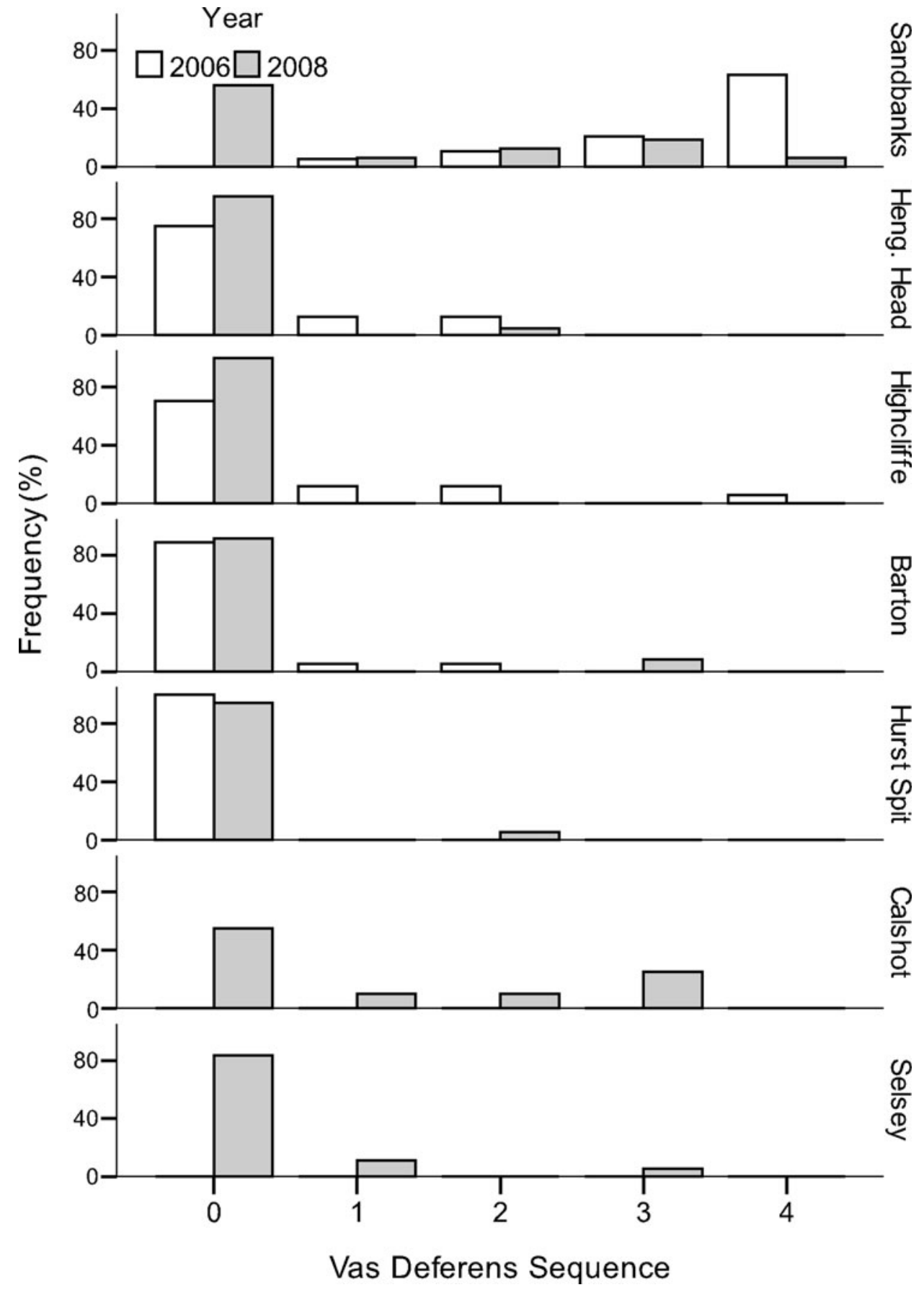

Fig. 2. The frequency of each vas deferens sequence stage for mainland Solent sites in 2006 and 2008. No imposex data were collected from Calshot and Selsey in 2006. No specimens exhibited stage 5 or stage 6 criteria.

food resources for dogwhelks indicate that the site is capable of supporting a population, yet the proximity of a port may be a key factor; its absence may be attributed to TBT levels as the site is within $1 \mathrm{~km}$ of Portsmouth Naval base and a commercial ferry route. Alternatively, it may be that recruitment is limited due to local hydrodynamics, and lack of nearby source populations; Lee-on Solent, itself with a small, isolated population, is $8.3 \mathrm{~km}$ away with extensive docks and dredged channels in between.

For mainland sites there was an overall decrease in RPSI between 2006 and 2008, except for at Barton-on-Sea and Hurst Spit, where although values increased (Table 1) they were still very low. The continued evidence of TBT impact in the Barton-on-Sea/Hengistbury Head/Hurst Spit area, which is distant from the larger regional harbours, may be due to persistent low level contamination or a local hotspot (perhaps TBT in sediments), or the irreversibility of imposex (Bryan et al., 1986). The lifespan of N. lapillus is typically around six years (Feare, 1970; Crothers, 1985) meaning that individuals alive when TBT concentrations were higher may still be present. In 2008 all sites had low RPSI-negligible in comparison with other south coast sites in the 1990 s (Spence et al., 1990; Evans et al., 1995, 1996; Huet et al., 1996), though they were apparently not completely 


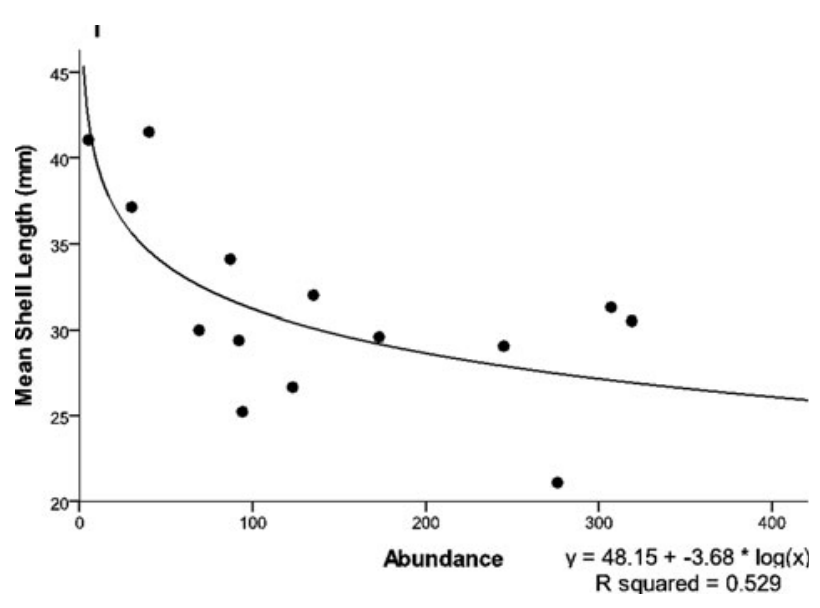

Fig. 3. Relationship between abundance and mean shell length at each, mainland Solent site in 2006 and 2008. Plot omits data (one individual) from Sowley in 2006 .

TBT-free; with the exception of Highcliffe where the increased population has colonized man-made groynes.

Similarities in shell lengths between sites several kilometres apart could simply be attributed to wave exposure (comparable at these locations) rather than an indication of population connectivity, as it has been shown to influence phenotypic expression in N. lapillus (Staiger, 1957; Kitching et al., 1966). However, medium distance movements of 10$100 \mathrm{~km}$ have proven fairly common for N. lapillus, assuming populations showing genetic similarity have been founded or augmented by one or another (Colson \& Hughes, 2004), though the means of travel are poorly understood. Hydrodynamic forces may carry individuals for distances of up to $1 \mathrm{~km}$ during storms (Bray, 2005) and N. lapillus individuals were found rolling between rock groynes at both Hengistbury Head and Highcliffe. In addition birds may drop individuals (Crothers, 1985), but dislodgement and passive transport is more likely.

Shore macrofauna can travel hundreds of kilometres by rafting (as adults or eggs) on detached clumps of floating seaweed (Ingólfson, 1995). To determine whether this is the case for $N$. lapillus, placing surface drifters and performing genetic examination could highlight whether gene flow follows the direction of the currents (Muhlin et al., 2008). The long-standing, relatively unaffected, intertidal populations on the south coast of the Isle of Wight (Herbert 1988; Bray \& Herbert, 1998) may have been a source of founding individuals on the mainland. Populations on the north coast of the Isle of Wight had become extinct by the mid-1980s (Herbert, 1988; Bray \& Herbert, 1998), yet have recovered since recolonizing individuals were observed in 1995 at East Cowes.

It is more likely that populations on the mainland are being replenished and/or augmented by dispersers from subtidal populations that have survived the worst of the contamination. Crothers $(1998,2003)$ postulated that a recolonized population of $N$. lapillus in Watermouth Cove in the Bristol Channel was repopulated by a subtidal population, taking 13 years to travel 30 miles. We noted a subtidal population on an outfall pipe at Hengistbury Head that extends into Christchurch Bay where there are shallow rocky ledges. Thus it may be that the Hurst Spit population was founded by subtidal colonizers, possibly explaining between-site 
similarity in cumulative shell lengths. Whether dispersers can form a viable population that persists in time depends on, amongst other things, demographic, environmental and genetic stochasticity (Shaffer, 1981), prey availability and also, more practically, engineering activity maintaining or changing sea defence structures. Some populations will not be successful because the habitat is unsuitable for them. This is most likely the case for Sowley where prevalence of prey was limited and substrates marginal, thus colonizers (as seen in 2006) cannot establish. The recovery of N. lapillus could be partly attributed to selection for individuals that have the ability to breed successfully, despite high concentrations of TBT (Birchenough et al., 2002; Huet et al., 1996, 2008). The recessive and uncommon male genital defect Dumpton Syndrome (DS) results in reduced penis size in males, and also in females affected by TBT (Gibbs, 1993) The condition was previously undetected, but TBT impacts highlighted it in some isolated populations (Gibbs, 2005) Populations exhibiting DS have survived in areas of high TBT contamination, as DS-affected females avert sterilization by imposex (Huet et al., 1996). Males taken from Calshot had smaller penis sizes than other sites, a symptom of DS. However, as DS occurs in isolated populations and this work suggests possible connectivity between recolonizing groups, this may be because of general underdevelopment.

This study shows that following UK restrictions on the use of TBT, N. lapillus populations in the southern UK region have recovered and spread into locations where they may not have been previously present. The evidence presented here leads us to hypothesize that this recovery may have been accelerated through the construction of new sea defences, as the animals have been found on these structures at locations where they were previously unrecorded. These structures provide a new habitat, offering intertidal 'stepping stones' to sites where dogwhelks may not have been previously present or were eliminated by TBT pollution some $30-40$ years ago. Some locations remain uncolonized, possibly due to residual TBT, or unsuitability and isolation; sites near to ports still show indications of TBT impact expressed as imposex, and no colonization has taken place within industrialized estuaries although extensive suitable substrate is present. The means of long-range dispersal of $N$. lapillus in the Solent remains unclear, but what has been demonstrated is that man-made substrates can provide useful habitat and facilitate more rapid recovery of $N$. lapillus as TBT pollution declines. For species with a short pelagic larval stage or with direct development, the population connectivity between patches of harder substrata may therefore be much greater than previously thought, even within a hydrodynamically complex region such as the Solent and central south coast of England.

\section{ACKNDWLEDGEMENTS}

The authors would like to thank John Crothers for his comments on an earlier version of the manuscript; Jenny Mallinson (National Oceanography Centre); and several volunteers who assisted with field data collection and David Lowthion (Team Leader, Marine Team SE, Environment Agency) who provided data on TBT. Three anonymous referees provided helpful comments which considerably improved this paper. This research received no specific grant from any funding agency, commercial or not-for-profit sectors.

\section{REFERENCES}

Adachi N. and Wada K. (1999) Distribution in relation to life history in the direct developing gastropod Batillaria cumingi (Batillariidae) on two shores of contrasting substrata. Journal of Molluscan Studies 65 , $275-287$.

Amos C.L., Sutherland T.F., Cloutier D. and Patterson S. (2000) Corrosion of a remoulded cohesive bed by saltating littorinid shells. Continental Shelf Research 20, 1291-1315.

Bacchiocchi F. and Airoldi L. (2003) Distribution and dynamics of epibiota on hard structures for coastal protection. Estuarine, Coastal and Shelf Science 56, 1157-1166.

Bates J.H. and Benson C. (1993) Marine environment law. London: Lloyd's of London Press Ltd.

Birchenough A.C., Evans S.M., Moss C. and Welch R. (2002) Re-colonisation and recovery of populations of dogwhelks Nucella lapillus (L.) on shores formerly subject to severe TBT contamination Marine Pollution Bulletin 44, 652-659.

Boersma P.D. and Parrish J.K. (1999) Limiting abuse: marine protected areas, a limited solution. Ecological Economics 31, 287-304.

Bray S. and Herbert R.J.H. (1998) A reassessment of populations of the dog-whelk (Nucella lapillus) on the Isle of Wight following legislation restricting the use of TBT antifouling paints. Proceedings of the Isle of Wight Natural History and Archaeological Society 14, 23-40.

Bray S. (2005) The long-term recovery of the bioindicator species Nucella lapillus from tributyltin pollution. $\mathrm{PhD}$ thesis. Southampton, University of Southampton.

Bryan G.W., Gibbs P.E., Hummerstone L.G. and Burt G.R. (1986) The decline of the gastropod Nucella lapillus around south-west England: evidence for the effect of tributyltin from antifouling paints. Journal of the Marine Biological Association of the United Kingdom 66, 497514 .

Bryan G.W. and Gibbs P.E. (1991) Impact of low concentrations of tributyltin (TBT) on marine organisms: a review. In Newman M.C. and McIntosh A.W. (eds) Metal ecotoxicology: concepts and applications. Boston: Lewis Publishers Inc, pp. 323-361.

Champ M.A. (2000) A review of organotin regulatory strategies, pending actions, related costs and benefits. Science of the Total Environment $258,21-71$

Chapman M.G. and Bulleri F. (2003) Intertidal seawalls-new features of landscape in intertidal environments. Landscape and Urban Planning $62,159-172$.

Colson I. and Hughes R.N. (2004) Rapid recovery of genetic diversity of dogwhelk (Nucella lapillus L.) populations after local extinction and recolonization contradicts predictions from life-history characteristics. Molecular Ecology 13, 2223-2233.

Crothers J.H. (1985) An introduction to the biology of Nucella lapillus (L.). Field Studies 6, 291-360.

Crothers J.H. (1998) The size and shape of dog-whelks, Nucella lapillus (L.) recolonising a site formerly polluted by tributyltin (TBT) in antifouling paint. Journal of Molluscan Studies 64, 127-129.

Crothers J.H. (2003) Further observations on a population of dog-whelks, Nucella lapillus (L.) recolonizing a site polluted by tributyltin (TBT) in antifouling paint. Journal of the Marine Biological Association of the United Kingdom 83, 1023-1027.

Dong P. (2004) An assessment of groyne performance in the United Kingdom. Coastal Management 32, 203-213.

Eggleton J. and Thomas K.V. (2004) A review of factors affecting the release and bioavailability of contaminants during sediment disturbance events. Environment International 30, 973-980. 
Evans S.M., Leksono T. and McKinnell P.D. (1995) Tributyltin pollution: a diminishing problem following legislation limiting the use of TBT-based antifouling paints. Marine Pollution Bulletin 30, 14-21.

Evans S.M., Evans P.M. and Leksono T. (1996) Widespread recovery of dogwhelks, Nucella lapillus (L.) from tributyltin contamination in the North Sea and the Clyde Sea. Marine Pollution Bulletin 32, 263-269.

Evans S.M., Nicholson G.J., Browning C., Hardman E., Seligman O. and Smith R. (1998) An assessment of tributyltin contamination in the North Atlantic using imposex in the dogwhelk Nucella lapillus (L.) as a biological indicator of TBT pollution. Invertebrate Reproduction and Development 34, 277-287.

Evans S.M., Kerrigan E. and Palmer N. (2000) Causes of imposex in the dogwhelk Nucella lapillus (L.) and its use as a biological indicator of tributyltin pollution. Marine Pollution Bulletin 40, 212-219.

Evans S.M. and Nicholson G.J. (2000) The use of imposex to assess tributyltin contamination in coastal waters and open seas. Science of the Total Environment 258, 73-80.

Feare C.J. (1970) The reproductive cycle of the dogwhelk (Nucella lapillus). Proceedings of the Malacological Society of London 39, 125-139.

Gibbs P.E. (1993) A male genital defect in the dog-whelk, Nucella lapillus (Neogastropoda), favouring the survival of a population in a TBT-polluted area. Journal of the Marine Biological Association of the United Kingdom 73, 667-678.

Gibbs P.E. (2005) Male genital defect (Dumpton syndrome) in the dogwhelk Nucella lapillus (Neogastropoda): Mendelian inheritance inferred, based on laboratory breeding experiments. Journal of the Marine Biological Association of the United Kingdom 85, 143-150.

Gibbs P.E. and Bryan G.W. (1986) Reproductive failure in populations of the dog-whelk, Nucella lapillus, caused by imposex induced by tributyltin from antifouling paints. Journal of the Marine Biological Association of the United Kingdom 66, 767-777.

Gibbs P.E., Bryan G.W., Pascoe P.L. and Burt G.R. (1987) The use of the dog whelk, Nucella lapillus, as an indicator of tributyltin (TBT) contamination. Journal of the Marine Biological Association of the United Kingdom 66, 507-523.

Gipperth L. (2009) The legal design of the international and European Union ban on tributyltin antifouling paint: direct and indirect effects. Journal of Environmental Management 90, 86-95.

Harding M.J.C., Bailey S.K. and Davies I.M. (1992) UK Department of the Environment, TBT imposex survey of the North Sea. Scottish Fisheries working paper No. 9/92. Contract No. 7/8/214, October 1992.

Harding M.J.C., Rodgers G.K., Davies I.M. and Moore J.J. (1997) Partial recovery of the dogwhelk (Nucella lapillus) in Sullom Voe, Shetland from tributyltin contamination. Marine Environmental Research 44, 285-304.

Hawkins S.J., Moore P.J., Burrows M.T., Poloczanska E., Mieszkowska N., Herbert R.J.H., Jenkins S.R., Thompson R.C., Genner M.J. and Southward A.J. (2008) Complex interactions in a rapidly changing world: responses of rocky shore communities to recent climate change. Climate Research 37, 123-133.

Hawkins S.J., Sugden H.E., Mieszkowska N., Moore P.J., Poloczanska E., Leaper R., Herbert R.J.H., Genner M.J., Moschella P.S., Thompson R.C., Jenkins S.R., Southward A.J. and Burrows M.T. (2009) Consequences of climate-driven biodiversity changes for ecosystem functioning of North European rocky shores. Marine Ecology Progress Series 396, 245-259.

Herbert R.J.H. (1988) A survey of the dogwhelk Nucella lapillus (L.) around the coast of the Isle of Wight. Proceedings of the Isle of Wight Archaeological and Natural History Society 8, 15-21.
Herbert R.J.H., Bray S. and Hawkins S.J. (2000) Use of the dog-whelk Nucella lapillus, as a bioindicator of tributyltin (TBT) contamination in the Solent and around the Isle of Wight. In Collins M.B. and Ansell K. (eds) Solent science-a review: Proceedings of the Solent Science Conference 1998. Oxford: Elsevier Science, pp. 307-310.

Herbert R.J.H., Southward A.J., Sheader M. and Hawkins S.J. (2007) Influence of recruitment and temperature on distribution of intertidal barnacles in the English Channel. Journal of the Marine Biological Association of the United Kingdom 87, 487-489.

Herbert R.J.H., Southward A.J., Sheader M. and Hawkins S.J. (2009) Persistent border: an analysis of the geographic boundary of an intertidal species. Marine Ecology Progress Series 379, 135-150.

Huet M., Paulet Y.M. and Le Pennec M. (1996) Survival of Nucella lapillus in a tributyltin-polluted area in west Brittany: a further example of a male genital defect (Dumpton syndrome) favouring survival. Marine Biology 125, 543-549.

Huet M., Le Goïc N. and Gibbs P.E. (2008) Appearance of a geneticallybased pollution resistance in a marine gastropod, Nucella lapillus, in south-west Brittany: a new case of Dumpton syndrome. Journal of the Marine Biological Association of the United Kingdom 88, 14751479 .

Ingólfson A. (1995) Floating clumps of seaweed around Iceland; natural microcosms and a means of dispersal for shore fauna. Marine Biology $122,13-21$.

Kitching J.A., Muntz L. and Ebling F.J. (1966) The ecology of Lough Ine. $\mathrm{XV}$. The ecological significance of shell and body forms in Nucella. Journal of Animal Ecology 35, 113-126.

Kotrikla A. (2009) Environmental management aspects for TBT antifouling wastes from the shipyards. Journal of Environmental Management $90,77-85$.

Langston W.J., Bryan G.W., Burt G.R. and Gibbs P.E. (1990) Assessing the impact of tin and TBT in estuaries and coastal regions. Functional Ecology 4, 433-443.

Langston W.J., Bryan G.W., Burt G.R. and Pope N.D. (1994) Effects of sediment metals on estuarine benthic organisms. National Rivers Authority R and D Note 203. Almondsbury, Bristol: NRA.

Langston W.J. and Pope N.D. (1995) Determinants of TBT adsorption and desorption in estuarine sediments. Marine Pollution Bulletin 31, $32-43$.

Largen M.J. (1967) The diet of the dog-whelk Nucella lapillus (Gastropoda: Prosobranchia). Journal of Zoology 151, 123-127.

Lewis J.R. (1964) The ecology of rocky shores. London: English Universities Press.

Maguire R.J. (2000) Review of the persistence, bioaccumulation and toxicity of tributyltin in aquatic environments in relation to Canada's toxic substances management policy. Water Quality Research Journal of Canada 35, 633-679.

Martel A. and Chia F. (1991) Drifting and dispersal of small bivalves and gastropods with direct development. Journal of Experimental Marine Biology and Ecology 150, 131-147.

Matthiessen P. and Gibbs P.E. (1998) Critical appraisal of the evidence for tributyltin-mediated endocrine disruption in molluscs. Environmental Toxicology and Chemistry 17, 37-43.

Miller K.L., Fernandes T.F. and Read P.A. (1999) The recovery of populations of dogwhelks suffering from imposex in the Firth of Forth 1987-1997/98. Environmental Pollution 106, 183-192.

Moore H.B. (1936) The biology of Purpura lapillus. 1. Shell variation in relation to environment. Journal of the Marine Biological Association of the United Kingdom 21, 61-89. 
Moore H.B. (1938) The biology of Purpura lapillus. III. Life history and relation to environmental factors. Journal of the Marine Biological Association of the United Kingdom 23, 67-74.

Morgan P.R. (1972) The influence of prey availability on the distribution and predatory behaviour of Nucella lapillus (L.). Journal of Animal Ecology 41, 257-274.

Morton B. (2009) Recovery from imposex by a population of the dogwhelk, Nucella lapillis (Gastropoda: Caenogastropoda), on the southeastern coast of England since May 2004: a 52-month study. Marine Pollution Bulletin 58, 1530-1538.

Moschella P.S., Abbiati M., Ĺberg P., Airoldi L., Anderson J.M., Bacchiocchi F., Bulleri F., Dinesen G.E., Frost M., Gacia E., Granhag L., Jonsson P.R., Satta M.P., Sundelof A., Thompson R.C. and Hawkins S.J. (2005) Low-crested coastal defence structures as artificial habitats for marine life: using ecological criteria in design. Coastal Engineering 52, 1053-1071.

Muhlin J.F., Engel C.R., Stressel C.R., Weatherbee R.A. and Brawley S.H. (2008) The influence of coastal topography, circulation patterns, and rafting in structuring populations of an intertidal alga. Molecular Ecology 17, 1198-1210.

Oliveira I.B., Richardson C.A., Sousa A.C., Takahashi S., Tanabe S. and Barroso C.M. (2009) Spatial and temporal evolution of imposex in dogwhelk Nucella lapillus (L.) populations from North Wales, UK Journal of Environmental Monitoring 11, 1462-1468.

Shaffer M.L. (1981) Minimum population sizes for species conservation. Bioscience 31, 131-134.

Siegel S. (1956) Nonparametric statistics. International student edition. New York: McGraw-Hill Book Company Inc. Library of Congress Catalogue Number 56-8185.

Smith A.J., Thain J.E. and Barry J. (2006) Exploring the use of caged Nucella lapillus to monitor changes to TBT hotspot areas: a trial in the River Tyne estuary (UK). Marine Environmental Research 62 $149-163$.

Sonak S., Pangam P., Giriyan A. and Hawaldar K. (2009) Implications of the ban on organotins for protection of global coastal and marine ecology. Journal of Environmental Management 90 (Supplement) s96-s108.

Spence S.K., Bryan G.W., Gibbs P.E., Masters D., Morris L. and Hawkins S.J. (1990) Effects of TBT contamination on Nucella populations. Functional Ecology 4, 425-432.
Staiger H. (1957) Genetical and morphological variation in Purpura lapillus with respect to local and regional differentiation of population groups. Annals of Biology 33, 251-258.

Stephenson T.A. and Stephenson A. (1949) The universal features of zonation on rocky shores. Journal of Ecology 37, 289-305.

Stephenson T.A. and Stephenson A. (1972) Life between tide-marks on rocky shores. San Francisco, CA: W.H. Freeman, 425 pp.

Svavarsson J., Granmo A., Ekelund R. and Szpunar J. (2001) Occurrence and effects of organotins on adult common whelk (Buccinum undatum) (Mollusca, Gastropoda) in harbours and in a simulated dredging situation. Marine Pollution Bulletin 42, 370-6.

Terlizzi A., Delos A.L., Garaventa F., Faimali M. and Geraci S. (2004) Limited effectiveness of marine protected areas: imposex in Hexaplex trunculus (Gastropoda, Muricidae) populations from Italian marine reserves. Marine Pollution Bulletin 48, 188-192.

Thomas K.V., Blake S.J. and Waldock M.J. (2000) Antifouling paint booster biocide contamination in UK marine sediments. Marine Pollution Bulletin 40, 739-745

Thomas K.V., Fileman T.W., Readman J.W. and Waldock M.J. (2001) Antifouling paint booster biocides in the UK coastal environment and potential risk of biological effects. Marine Pollution Bulletin 42, 677688.

and

Williams E., Bray S., Lloyd Jones D., Steyl I., Hudson M.D. and Nicholls R.J. (2009) Scoping study: site analysis for potential beneficial dredge spoil use for restoration and recharge of intertidal soft sediment resources within the Solent. Report to Hampshire County Council and the Environment Agency, University of Southampton, School of Civil Engineering and the Environment.

\section{Correspondence should be addressed to:}

M.D. Hudson

Faculty of Engineering and Environment

University of Southampton

Highfield, Southampton, Hampshire, SO17 1B)

email: mdh@soton.ac.uk 